\title{
High ownership concentration and exporting of emerging market firms: evidence from Peru
}

\author{
William Gonzalo Vega Salas ${ }^{1,2}$ and Ziliang Deng ${ }^{1 *}$
}

\author{
* Correspondence: \\ ziliang.deng@ruc.edu.cn \\ ${ }^{1}$ Renmin Business School, Renmin \\ University of China, Haidian, Beijing, \\ China \\ Full list of author information is \\ available at the end of the article
}

\begin{abstract}
Despite the extraordinarily high ownership concentration widely observed in emerging market firms as a result of institutional voids, there is little research on how this high ownership concentration affects the exporting behavior of emerging market firms. From principal-agent and institutional perspectives, we hypothesize that high ownership concentration has a negative relationship with export intensity, because, in emerging markets, highly concentrated ownership bridges the interests of owners (principals) and managers (agents) so that principals must be prudent in exploring risky international markets. Moreover, we hypothesize that export country diversification strengthens the relationship between ownership concentration and export intensity, because broad geographic dispersion increases risk exposure and principal-agent problems. Empirical analysis based on a panel dataset for publicly listed firms in Peru from 2005 to 2014 supports the hypotheses. The study highlights the risk aversion attitude activated by ownership concentration, an attitude that protects emerging market firms from overconfidently exploring international business opportunities. The study extends the conventional literature on the interface between ownership concentration and international business in an emerging market context. We also discuss the generalizability of the findings to other emerging markets, e.g. China.

Keywords: Ownership concentration, Export, Country diversification, Agency theory, Emerging markets, Peru
\end{abstract}

\section{Introduction}

The impact of corporate governance on the international business of firms is attracting increasing attention. Although it is expected that the way in which ownership concentration affects emerging market firms will be influenced by their institutional environment, this has not yet been extensively examined (Gaur \& Delios, 2015). Emerging markets have had an important impact on global business over the last 20 years (Bhaumik, Estrin, \& Mickiewicz, 2017) and host $80 \%$ of the world's population, but extensive studies on ownership concentration have mostly been done in the context of developed economies (Hoskisson \& Turk, 1990), and the findings from such studies are not necessarily applicable to emerging markets (Young, Peng, Ahlstrom, Bruton, \& Jiang, 2008). Emerging markets account for $45 \%$ of world trade (Gaur \& Delios, 2015) and suffer from challenges not found in developed economies (Doh, McGuire, \& Ozaki, 2015). Therefore emerging markets provide

(c) The Author(s). 2017 Open Access This article is distributed under the terms of the Creative Commons Attribution 4.0 International License (http://creativecommons.org/licenses/by/4.0/), which permits unrestricted use, distribution, and reproduction in any medium, provided you give appropriate credit to the original author(s) and the source, provide a link to the Creative Commons license, and indicate if changes were made. 
important examples in which the relationship between ownership concentration and exporting can be studied.

The unique institutional environments of emerging markets provide a field in which to reexamine the impact of high ownership concentration on exporting. Institutions influence the performance of an economy and determine the routines, actions, and outcomes of firms. Recent literature has begun to explore the role of institutions in corporate governance, especially in emerging markets (Wan, 2005; Wright, Hoskisson, \& Peng, 2005), which are characterized by institutional voids (Doh et al., 2015). The conditions imposed by formal institutions in emerging markets are different from those imposed in developed economies, which have been extensively studied (Wright et al., 2005). The poor legal protection and weak institutions that can be found in emerging markets (Denis \& McConnell, 2003) result in high ownership concentration, as this is a way to shelter investors (principals) from other investors (principals) and managers (agents) (Perotti \& Von Thadden, 2006). For instance, in some emerging markets the largest shareholders typically possess over $50 \%$ of the equity of a firm, while in developed economies that figure is usually below $40 \%$ (Young et al., 2008). In this research, the average of the three top owners reaches $80 \%$ of the shares. This concentration is not only higher than the average concentration but also it is higher than the average found in other emerging markets.

High ownership concentration plays an important controlling and coordinating role in emerging markets. Those markets typically feature weak laws and regulations, and weak protection and enforcement, so corporate governance has relatively weak support from institutions (Peng, 2003). The formation of informal institutions, such as relational ties, government contacts, business groups and family business, becomes common, and fills the institutional voids (Peng \& Heath, 1996). Ownership concentration therefore, to some extent, alleviates principal-agent conflicts in emerging markets (Bhaumik et al., 2017). Consequently, the large shareholders of firms in emerging markets are characterized by high control and coordination and low information asymmetry (Burkart \& Panunzi, 2006). Senior managers therefore usually have stronger communication mechanisms with shareholders and work more in line with the best interests of the firm in the local market. Given the high uncertainties and information asymmetry involved in export markets (Ramaswamy, 1993), a question naturally arises: does ownership concentration in emerging market firms help to reduce their risk-taking activities such as exporting? The literature has identified the resources and capabilities needed for exporting, but the effect of corporate governance on exporting remains underexplored. The limited studies that do exist have mainly focused on developed economies, where institutions to protect investors are well developed so that firms do not turn to ownership concentration for protection (Oesterle, Richta, \& Fisch, 2013).

In order to answer this intriguing question, we examine the exporting of firms with high ownership concentration in an emerging market context from the principal-agent and institutional perspectives. We hypothesize that high ownership concentration in an emerging market results in prudent and risk-averse strategic decisions, and thus exerts a negative influence on the risky exporting behavior of the firm. We further hypothesize that export country diversification poses higher uncertainties to firms, and therefore accentuates the negative relationship between ownership concentration and export intensity. 
Previous studies suggest incorporating the analysis of governance issues in future analyses of exporting in emerging countries (Filatotchev, Stephan, \& Jindra, 2008) since governance varies both between and within countries (La Porta, Lopez-De-Silanes, Shleifer, \& Vishny, 1997). Even though there is growing empirical research in emerging markets, most is concentrated in countries such as China, India, Brazil and Russia. Peru shows a higher ownership concentration compared with the average level of emerging markets, and also continues to have exporting as the main entry mode of international expansion.

Previous studies have connected ownership structure with the propensity to export and export intensity (Fernandez \& Nieto, 2006) and with new foreign investment (Singh \& Gaur, 2013), among others. By and large, the literature still scarcely considers the magnitude of the activities of the firm in different countries. In some studies, the firm's diversification is evaluated only by the number of countries that the firm has entered (George, Wiklund, \& Zahra, 2005). Therefore, in this research, we consider country diversification with measures incorporating magnitude and scope.

We construct a unique panel database of listed Peruvian firms from three sources, for the years between 2005 and 2014. Tobit regression models are employed to conduct the analyses. Peru provides an appropriate research setting because it is an emerging economy in which corruption and inefficiency in the public sector, among other variables related to institutions, represent the biggest challenges for doing business (Department for International Trade of UK, 2014). Meanwhile major reforms, such as the privatization of most state-owned enterprises and trade liberalization, have been carried out since the 1990s.

\section{Literature}

Previous research argues that export expansion is related to factors such as firm size, age, affiliation, etc. In this study, we argue from a principal-agent perspective that there is a relationship between ownership concentration and export intensity in emerging markets. As weak institutions in emerging markets make principals more concerned with control and monitoring agents, ownership concentration arises as a way to protect the interest of principals (Deng, Hofman, \& Newman, 2013; Li, Guo, Yi, \& Liu, 2010). Therefore, the principal-agent perspective becomes important to analyze the relationship between ownership concentration and export intensity. Since exporting involves stronger asymmetry of information, increasing the possibility of opportunist behavior by the agent, an increasing risk affects the role of principals in a high ownership concentration situation. To that end, agency theory can be used to explain the behavior of managers and investors.

There have been mixed empirical findings in the literature about the influence of ownership concentration on firm performance. Some argue that principals with concentrated ownership tend to support decisions that maximize firm efficiency (Hill \& Snell, 1989). In contrast, some argue that there is a negative relationship, because high ownership concentration makes the principals limit the decisions and activities of the managers, especially when the principals pursue their own goals that may not be the same as the firm's goal, so that international diversification is not supported. Other authors argue that the decision to buy shares in a firm is influenced by the profit maximizing interest of the shareholders (Demsetz \& Villalonga, 2001). Therefore, when the market is efficient, ownership concentration is irrelevant for the firm. With these mixed results, it is necessary to join this discussion and extend the boundaries of the literature with an international dimension, e.g. incorporating exporting and the diversification of exports to different country destinations. 
Institutions in emerging markets provide us with a suitable environment to study this phenomenon. Institutions in emerging markets are characterized by rapid changes that increase the ambiguity of the decision-making process for managers. As a consequence the principal-agent conflict between shareholders and managers may arise. With these weak institutions in emerging countries, principals have stronger incentives to control decisions and the properties of the firm. Several studies have highlighted that blockholders have incentives to monitor, control and interfere with the process of internationalization (Filatotchev \& Wright, 2011).

Ownership concentration is the ownership share of the largest owners in a firm (Thomsen \& Pedersen, 2000). In emerging markets, ownership concentration is a widely observed pattern, even in the largest companies (La Porta, Lopez-de-Silanes, \& Shleifer, 1999). Ownership concentration matters for firm strategy, innovation, and performance (Bhaumik et al., 2017; Bozec, 2005), since large shareholders can exert a fundamental influence on a firm. When there is high ownership concentration, majority shareholders can focus better on firm strategies, putting less effort into coordination between principals, so the firm can maximize benefits and reduce costs more effectively (Demsetz \& Lehn, 1985). Indeed, the owners' tighter control over the managers could result in more efficiency (Burkart \& Panunzi, 2006) and a higher long-term commitment (Bhaumik et al., 2017). On most occasions ownership concentration alleviates the conflict between principals and agents (Huddart, 1993), and this is particularly true in emerging markets. But if we study the influence of ownership concentration on a firm's international expansion the results could be different, considering that exports increase the asymmetry of information generating an increase in costs due to difficulties in coordination and control. Moreover, firms with high ownership concentration lack adaptability to environmental change (Burkart \& Panunzi, 2006).

Previous research on Chinese firms analyzed the relationship between ownership concentration and export propensity from a principal-principal perspective. Some concluded that, regarding high ownership concentration, firms pursue different goals from profit seeking which may result in using resources from international strategy to accomplish domestic goals, even when there are opportunities for international expansion (Lu, Xu, \& Liu, 2009). Thus, it would be intriguing to analyze, from a principalagent perspective, the relationship between high ownership concentration and export intensity and compare to previous findings.

\section{Hypotheses}

High ownership concentration and export intensity

Export intensity refers to the share of total sales contributed by exports. It is one of the most frequently adopted measures of the degree of internationalization of an exporter (Filatotchev et al., 2008). According to agency theory, principals do not have knowledge or time to lead the firm, so principals delegate certain functions and responsibilities to agents in order to run the firm on their behalf. However, agents could have different interests. There is a knowledge gap between agents and principals, and it is costly to control and monitor the agents. Therefore, when the knowledge gap is too wide for the principals, the principals tend to carry out control and monitoring though ownership concentration to minimize risks. Therefore, principals try to avoid activities that involve 
risk. As emerging markets have weak or ineffective institutional infrastructures (Liu, Li, \& Xue, 2011), ownership concentration arises as a way to avoid free-riding behavior and managerial opportunism. In a local market with high ownership concentration, it is easier for owners to control managers and to coordinate with them (Burkart \& Panunzi, 2006). When ownership is dispersed, owners incur high monitoring and control costs to get a small share of the benefits. So firms in emerging markets put more emphasis on internal control mechanisms (Peng \& Heath, 1996), and principals have a greater motivation to monitor agents (Jensen \& Meckling, 1976).

When ownership is highly concentrated, agents are constrained and must follow the principals' interests (Hill \& Snell, 1989), so that concentration alleviates principal-agent problems (Majocchi \& Strange, 2012). Agents in listed companies are usually appointed by the blockholders (Young et al., 2008) and must be responsible for the ultimate interests of the blockholders. Therefore principals and agents share a highly similar attitude toward market risks, and managers are mainly motivated by the largest shareholders when they take decisions (Grosfeld \& Tressel, 2002).

As stated, the environment in emerging markets makes ownership concentration beneficial for the firm and agent-principal conflict is limited. Likewise firms that generate core competencies in the internal market tend to use the same competencies in the process of internationalization based on the profitability of those competencies in the home market (Hitt, Hoskisson, \& Kim, 1997). However, those competencies are not necessarily suitable in the international market. Features such as high control, strong coordination and low asymmetry of information are important and enable firms to succeed with high ownership concentration by taking advantage of the institutions in the local market (Wan, 2005). However, in the process of internationalization firms need to adjust to new cultures, circumstances, costs, etc. Thus, a firm's environment becomes more complex and monitoring becomes more important (Young et al., 2008).

Firms in emerging markets with concentrated ownership are averse to risks, such as exporting to an unknown new market. In exploring export market opportunities, the owners need to delegate authority and responsibility to managers (Sanders \& Carpenter, 1998), since the large shareholders lack direct knowledge of international markets (Child \& Rodrigues, 2005). The process of exporting therefore inevitably demands more knowledge, and increases the risks involved in political situations or foreign exchange, among others (Doh et al., 2015). The complexity of operations in the exporting process drives the firm to delegate more decision-making powers to the agent (Sanders \& Carpenter, 1998). At the same time, it makes it increasingly difficult for the owners to control the managers' performance directly, and the asymmetry of information between the principal and the agents becomes greater. Therefore an agency problem potentially arises (Gomez mejia \& Balkin, 1992). To avoid such problems, the owners tend to request the managers to lower export intensity.

Hypothesis 1 (H1): High ownership concentration has a negative relationship with export intensity.

\section{Moderating role of export country diversification}

International diversification has been defined as a firm's expansion from its home country to different overseas markets (Welch \& Luostarinen, 1988). The process of international diversification, through trading with more export destinations, involves more 
complex information processing. Firms need to spend greater resources on dealing with different government regulations, trade laws, logistics, cultural diversities and other factors (Hitt et al., 1997). Therefore, principals are reluctant to diversify by dispersion because such diversification makes exporting managers more indispensable to the firm, increasing their autonomy and private benefit (Oesterle et al., 2013). Moreover, efforts to increase geographic dispersion increase financial and organizational pressures, coordination, distribution and management costs. Thus, increasing export country diversification has a negative moderating effect on export intensity, since it generates more asymmetry of information and at the same time more conflict between principals and agents, resulting in more risk exposure for the principals.

On the contrary, when export country diversification is low, firms can get faster reactions on the needs of limited markets, and gain a better position in existing markets (Contractor, 2007). Concentrating exports on a few markets can result in stronger expertise in those markets and superior performance especially for firms from small countries. In emerging markets there is a limitation of managerial, financial and knowledge resources about international markets, therefore with high ownership concentration, principals of exporting firms are more likely to have relatively higher export intensity when export country diversification is at a relatively low level.

Hypothesis 2 (H2): Export country diversification strengthens the negative relationship between high ownership concentration and export intensity.

Figure 1 sketches the theoretical framework.

\section{Method}

\section{The Peruvian context}

Latin America is an intriguing region for the study of ownership concentration and exports, as exporting is the main mode of internationalization in emerging markets (Welch \& Luostarinen, 1988). Firms with concentrated ownership have an important influence in emerging regions such as Asia and Latin America because of the unique institutions and backgrounds of these regions. The case of Latin America is even more interesting because the average degree of concentration of the largest owners is higher than that in the US, Europe or Asia, even after the processes of liberalization and democratization in the 1980s. Ownership concentration remains high in local business groups, so changes in the ownership structures have not been widely observed (Aguilera \& Crespi-Cladera, 2016). This makes this region an important area for research on ownership concentration (Adler, Doktor, \& Redding, 1986).

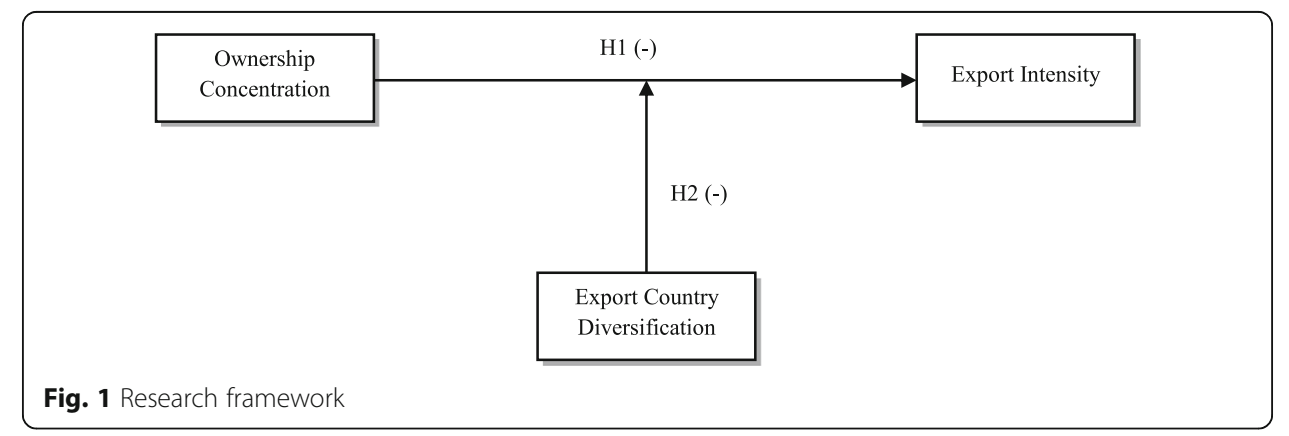


Among Latin American countries, Peru offers an appropriate setting for this study for the following reason: in the process of serving foreign markets, exporting is still an important mode of foreign entry. Since the 1990s Peru has reformed its policies to create an open economy, and now has a post-liberalization context. As was the case previously in Asia (Bhaumik et al., 2017), exporting has become a convenient and necessary option for Peruvian firms. Since the economy is undergoing a process of liberalization, there has been increased competition inside the country, so firms are pressed to engage in exporting. As a result, diversification has become an important option for survival (Dawar \& Frost, 1999), for improving firm performance, and for expanding a firm's markets (Campa \& Guillen, 1999). The country has an ambitious program for international commerce. It has signed free trade agreements with several important economies, such as the USA, China, the European Union, and Japan, ${ }^{1}$ which encourages firms to engage in exports. Peru ranks second in the Latin America and the Caribbean region for facilitating international business, according to measures on the facilitation of the regulatory environment for local businesses (The World Bank, 2006). Exporting has therefore become a more easily available option for Peruvian firms.

Most studies covered in the literature was initially done in developed countries, but now emerging markets are becoming an important research context (Leonidou, Katsikeas, \& Coudounaris, 2010). This includes the study of export behavior (Peng \& Ilinitch, 1998), but so far China, India, Brazil, and Russia have attracted the majority of the attention for researchers in international business and emerging economies (Chang \& Xu, 2008; Filatotchev, Dyomina, Wright, \& Buck, 2001; Singh \& Gaur, 2013). There are, however, other emerging countries such as Peru with a different culture, language, etc., that can provide a different perspective. As an emerging economy, the institutional environment in Peru is changing rapidly, which had an important influence on business decisions, performance, governance and internationalization (Peng, 2003) representing an important location for the study of a firm's internationalization in emerging markets in contrast with other emerging countries such as China.

We use data on Peruvian firms during the period 2005-2014 that are primarily obtained from three different sources. The first dataset is the BvD Osiris database. This provides annual, firm-level information about Peruvian firms including return on assets, solvency ratio, sales and size. The second data source is the Peruvian stock market. From the stock market statistics we were able to calculate ownership concentration. We checked year by year and firm by firm through different annual reports to consolidate information about the ownership concentration variable. The third source is the Peruvian customs office, which reports data on industry and exporting. This source of information gives us quite detailed and comprehensive information about the export value per firm, per year, and per export destination country. We combined the first and the second data base and then we selected those firms that exported at least once during the sample period. While the availability of accurate data and longitudinal data is usually a limitation in the analysis of emerging economies (Hoskisson, Eden, Lau, \& Wright, 2000), we were able to obtain information regarding corporate governance, exporting and other financial information for 84 firms.

In this research we leveraged the advantages of longitudinal data. Ten years of panel data capture firm dynamism, which is a good foundation for a more accurate inference of the model parameters and allows us to control the effect of missing or unobserved 
variables (Hitt, Tihanyi, Miller, \& Connelly, 2006). The sample size is equivalent to that of similar studies. In the literature about international diversification, there have been a large number of studies that use a sample of fewer than 100 firms (Hitt et al., 2006).

\section{Variables}

\section{Dependent variable}

To measure export intensity we use the share of foreign sales in total sales (Collins, 1990; Fernandez \& Nieto, 2006; Grant, Jammine, \& Thomas, 1988; Stopford \& Wells, 1972; Tallman \& Li, 1996). This measure reflects the depth of a firm's internationalization (Geringer, Beamish, \& Dacosta, 1989). We multiply this variable by 100 so that its scale ranges from 0 to 100 , and the estimated coefficients do not seem trivial.

\section{Independent variable}

The main independent variable is ownership concentration. This represents the ownership share of the largest owners in the firm (Li, Sun, \& Liu, 2006; Thomsen \& Pedersen, 2000). Some extant studies measure ownership concentration with the shares owned by the five or ten largest shareholders (Demsetz \& Lehn, 1985), giving more weight to the five largest shareholders (Demsetz \& Villalonga, 2001). Researchers working on US or UK companies often use the equity of the five largest shareholders to indicate the presence of owners who exercise control over the firm (Dharwadkar, George, \& Brandes, 2000). In emerging markets ownership concentration is a widely observed pattern, even in the largest companies (La Porta et al., 1999; Young et al., 2008). In this study, too, the largest three shareholders, on average, hold $80 \%$ of the shares of the firm, so taking into account more shareholders when measuring ownership concentration is less relevant because the exercise of control and decision-making in the firm by the fourth and fifth largest shareholders is very small and weak. Thus for this research we consider no more than the sum of the shares of the three largest shareholders, following the practice adopted in previous research in Chile (Morales, Meléndez, \& Ramírez, 2013), another emerging economy in Latin America. In order to measure the ownership concentration in this research, we use three categories. For the ownership share of the largest owner, we use top 1 shareholder concentration as the independent variable. For the sum of the ownership shares of the two largest owners, we use top 2 shareholder concentration. For the sum of the ownership shares of the three largest owners, we use top 3 shareholder concentration.

\section{Moderating variable}

To test H2, we use export country diversification as the moderating variable. Some literature measures diversification using a country scope measure (the number of countries where there are subsidiary operations or the number of a firm's export destinations (George, Wiklund, \& Zahra, 2005; Ramaswamy, 1993; Tallman \& Li, 1996). However, it is not appropriate when considering export-related exposure to country risks, since firms can export products as samples or in very small quantities but should still be considered as participating in exports. ${ }^{2}$ For this research, we use the Herfindahl index to measure country export diversification, since this index measures diversification according to the total sales and sales proportion per destination. The major benefit of the Herfindahl index is that it gives more weight to sales, so it can comprehensively measure diversification. It has also been used in previous research to measure export 
concentration (Lawless, 2010). Therefore, the export country diversification is: $1-\Sigma S_{j}^{2}$, where $S_{j}^{2}$ is the proportion of the firm's exports that go to country $j$, squared. ${ }^{3}$

\section{Control variables}

The rate of profitability (Zhou \& Guillén, 2015), represented by the return on total assets $(R O A)$, is important for measuring the firm's financial performance or how the firm is using its assets. We expect profitability to have an influence on export intensity, since firms that have strong financial resources can invest in promoting exports.

We use a variable measuring the solvency ratio (solvency) to represent the firm's ability to meet its debts, other obligations and new business ventures. Previous research has found that exporters have more liquidity than non-exporters, and that firms that are only starting to export have lower liquidity than continuing exporters (Greenaway, Guariglia, \& Kneller, 2007), so that liquidity is an important factor for exporters. Another previous study highlights the importance of internal resources in order to exploit international opportunities but at the same time this cost produces diminishing returns, risk and can influence the decision to export (Hitt et al., 1997).

We also include firm experience as a control variable. This represents the firm's age in years from the establishment to time $t$ (Chang, Chung, \& Moon, 2013). It is important to include this variable since the accumulation of knowledge by the firm can influence the decision to trade with new destinations.

The size variable represents the magnitude, dimension or extent of the firm. Previous analysis has measured a firm's size by the logarithm of its assets (Hennart, Dongjae, \& Ming, 1998), its total sales (Chang \& Xu, 2008), or the logarithm of the number of its employees (Salomon \& Jin, 2010). In this study the size is measured by the turnover per employee in the industry, the total assets and the number of employees. ${ }^{4}$ The extent of the firm is represented by the sales in millions of US\$. This is important, since sales are the initial point for resource generation, and resources are important for promoting or financing exports to new destinations.

The institutional distance has an influence in international expansion (Santangelo \& Meyer, 2011; Wan, 2005), so we incorporate a measure built on the Index of Economic Freedom from the Heritage Foundation and the weighted exports for each firm. Finally, we also include industry dummy variables and year dummy variables to control for the disturbances caused by sectoral factors and business cycles.

\section{Model}

We designed a Tobit model for the regressions. Our data has a substantial portion of firms that have zero exports, so linear models would lead to biased and negative fitted values, and cause severe estimation bias (Wooldridge, 2002). To avoid this bias it is vital to employ a Tobit model rather than a traditional linear regression model. We evaluate the significance of the independent variables on the dependent variable by using the Tobit model in the Stata 12.0 software package. We can specify two groups of models: the first one in order to determine the relationship between top 1, top 2 and top 3 ownership concentration variables and export intensity; the second one analyzes the moderator role of export country diversification in the previous relationship. We can specify the models as follows: 


$$
\begin{aligned}
& \mathrm{H} 1 \text { : export intensity }{ }^{*}=\alpha_{0} \\
& +\alpha_{1} \text { ownership concentration }+\boldsymbol{\beta} \times \boldsymbol{X}+\varepsilon_{1} \\
& \begin{aligned}
\mathrm{H} 2 \text { : export intensity }{ }^{*}=\lambda_{0} & +\lambda_{1} \text { ownership concentration } \\
& +\lambda_{2} \text { ownership concentration } \\
& \times \text { export country diversification }+\gamma \times \boldsymbol{X} \\
& +\varepsilon_{2} \text { export intensity }=\max \left(0, \text { export intensity }{ }^{*}\right),
\end{aligned}
\end{aligned}
$$

where $\boldsymbol{X}$ denotes a vector of control variables. Latent variable export intensity ${ }^{*}$ has a normal homoscedastic distribution (Wooldridge, 2002, p. 540).

\section{Results}

Table 1 reports the distribution of the sampled firms in the top 20 sectors. This table provides information about the exported products classified by the HS code (2 digits) followed by the number of firms, the export value (US\$), the number of export destinations, and the average ownership concentration. The top three sectors for exports account for more than $50 \%$ of the total export value and are represented by commodities such as ores, oil, and metals, indicating that commodities and raw materials are the dominant exports.

Table 2 provides descriptive statistics for the variables, and the correlation coefficients among the variables. The average equity participation of the top one, two and three largest shareholders is $58 \%, 73 \%$, and $80 \%$, respectively. The shares of the fourth, fifth and other shareholders in the control and decisions in the firm are very small and relatively irrelevant for this study. The extremely high ownership concentrations justify our choice of the top one, two, and three shareholders to measure the ownership concentration in the firm. They also justify Peru as an appropriate research context for analyzing the relationship between high ownership concentration and exporting.

The Tobit regression results for the relationship between ownership concentration, represented by the top one, two, and three shareholders, and export intensity show a negative significant relationship, as we can see in the first, second and third columns of Table 3. The empirical results confirm H1, suggesting that principals try to avoid large export intensity since it involves risk, generated by the need to give more freedom and authority to the agent, increasing the asymmetry of information and the possibility of opportunistic behavior. $\mathrm{H} 2$ is supported too. In the fourth, fifth and sixth columns of Table 3 we can see that the country export diversification significantly moderates the relationship between ownership concentration in top 1, top 2, and top 3 ownership concentration and export intensity.

\section{Robustness test}

We used a robustness test by substituting the export country diversification using the entropy measure of international diversification, which has been widely documented in the recent international business literature (e.g. Deng, Jean, \& Sinkovics, 2017; Hitt et al., 1997; Qian, Khoury, Peng, \& Qian, 2010). This new internationalization measure considers sales at the country level and the proportion of those sales in terms of the firm's total exports which result in a consistent regional diversification index. The entropy measure of diversification is defined as: $\sum_{i}\left[P_{i} \times \ln \left(1 / P_{i}\right)\right], P_{i}$ is the sales in 
Table 1 Sector distribution of exporting activities, 2005-2014

\begin{tabular}{|c|c|c|c|c|c|c|c|}
\hline Rank & $\begin{array}{l}\text { Sector HS } \\
\text { code }\end{array}$ & Sector name & $\begin{array}{l}\text { Value, } \\
\text { USD million }\end{array}$ & \# of firms & $\begin{array}{l}\text { Accumulated } \\
\text { share (\%) }\end{array}$ & \# of destinations & $\begin{array}{l}\text { Average ownership } \\
\text { concentration }\end{array}$ \\
\hline 1 & 26 & Ores, slag and ash & 5322.34 & 13 & 30 & 29 & 0.59 \\
\hline 2 & 27 & $\begin{array}{l}\text { Mineral fuels, oils, } \\
\text { distillation products }\end{array}$ & 2777.47 & 13 & 45 & 29 & 0.60 \\
\hline 3 & 71 & $\begin{array}{l}\text { Pearls, precious stones, } \\
\text { metals, coins }\end{array}$ & 1645.79 & 9 & 54 & 17 & 0.62 \\
\hline 4 & 74 & Copper and articles thereof & 1525.20 & 12 & 63 & 22 & 0.92 \\
\hline 5 & 23 & $\begin{array}{l}\text { Residues, food industry waste, } \\
\text { animal fodder }\end{array}$ & 1082.33 & 5 & 69 & 36 & 0.66 \\
\hline 6 & 72 & Iron and steel & 825.92 & 13 & 73 & 24 & 0.44 \\
\hline 7 & 28 & $\begin{array}{l}\text { Inorganic chemicals, } \\
\text { precious metal compound }\end{array}$ & 634.58 & 13 & 77 & 77 & 0.91 \\
\hline 8 & 40 & Rubber and articles thereof & 558.11 & 16 & 80 & 53 & 0.90 \\
\hline 9 & 79 & Zinc and articles thereof & 539.84 & 2 & 83 & 72 & 0.87 \\
\hline 10 & 51 & $\begin{array}{l}\text { Wool, animal hair, horsehair } \\
\text { yarn and fabric }\end{array}$ & 473.21 & 1 & 86 & 61 & 0.30 \\
\hline 11 & 85 & Electrical, electronic equipment & 350.41 & 36 & 88 & 41 & 0.80 \\
\hline 12 & 61 & $\begin{array}{l}\text { Articles of apparel, accessories, } \\
\text { knit or crochet }\end{array}$ & 257.68 & 12 & 89 & 45 & 0.49 \\
\hline 13 & 52 & Cotton & 221.34 & 4 & 90 & 42 & 0.70 \\
\hline 14 & 15 & $\begin{array}{l}\text { Animal, vegetable fats and } \\
\text { oils, cleavage products }\end{array}$ & 199.24 & 4 & 92 & 27 & 0.71 \\
\hline 15 & 17 & Sugars and sugar confectionery & 195.09 & 7 & 93 & 16 & 0.79 \\
\hline 16 & 62 & $\begin{array}{l}\text { Articles of apparel, accessories, } \\
\text { not knit or crochet }\end{array}$ & 136.45 & 7 & 93 & 49 & 0.46 \\
\hline 17 & 25 & $\begin{array}{l}\text { Salt, sulphur, earth, stone, } \\
\text { plaster, lime and cement }\end{array}$ & 116.66 & 18 & 94 & 29 & 0.85 \\
\hline 18 & 34 & $\begin{array}{l}\text { Soaps, lubricants, waxes, } \\
\text { candles, modelling pastes }\end{array}$ & 116.05 & 6 & 95 & 37 & 0.98 \\
\hline 19 & 20 & $\begin{array}{l}\text { Vegetable, fruit, } \\
\text { nut food preparations }\end{array}$ & 114.08 & 4 & 95 & 37 & 0.74 \\
\hline 20 & 22 & Beverages, spirits and vinegar & 103.55 & 14 & 96 & 33 & 0.76 \\
\hline
\end{tabular}

overseas market region $i$ and $\ln \left(1 / P_{i}\right)$ is the weight. The results in the seventh, eighth and ninth columns of Table 3 suggest the validity to measure diversification.

\section{Conclusion}

\section{Discussion}

From this study we conclude that, in emerging markets with significant institutional voids, the widely observed high ownership concentration suggests the necessity of re-examining the conventional principal-agent conflict (Demsetz \& Lehn, 1985; Grossman \& Hart, 1986). Institutions in emerging markets are weaker, so they give standard corporate governance less support (Cardoza, Fornes, Farber, Gonzalez Duarte, \& Ruiz Gutierrez, 2016; Peng, 2003). Therefore, ownership concentration emerges as a way to protect the principals' investment in the firm. Ownership concentration in emerging markets is high to protect principals' investment, so firms are characterized by high control and coordination, and low asymmetry of information. But the complexity of operations in exporting, e.g. that the firm delegates more authority and responsibility to managers (i.e. agents) (Sanders \& Carpenter, 1998), would result in a potential reduction in the control and coordination of the 
Table 2 Correlation coefficients and descriptive analysis

\begin{tabular}{llllllllllll}
\hline Variables & 1 & 2 & 3 & 4 & 5 & 6 & 7 & 8 & 9 & 10 & 11 \\
\hline $\begin{array}{l}\text { 1. Top 1 Ownership } \\
\text { concentration }\end{array}$ & 1.00 & & & & & & & & & \\
2. Top 2 Ownership & 0.87 & 1.00 & & & & & & & & \\
concentration & & & & & & & & & & \\
3. Top 3 Ownership & 0.80 & 0.97 & 1.00 & & & & & & & \\
concentration & & & & & & & & & & \\
4. Export Intensity & -0.01 & 0.01 & 0.00 & 1.00 & & & & & & \\
5. Country diversification & -0.19 & -0.14 & -0.16 & 0.36 & 1.00 & & & & & \\
6. ROA & 0.12 & 0.06 & 0.03 & 0.06 & 0.00 & 1.00 & & & & \\
7. Solvency ratio & 0.14 & 0.05 & 0.01 & -0.04 & 0.10 & 0.19 & 1.00 & & & \\
8. Experience & -0.29 & -0.25 & -0.26 & -0.08 & 0.31 & -0.02 & 0.08 & 1.00 & & \\
9. Size & -0.17 & -0.23 & -0.21 & -0.07 & -0.10 & 0.01 & 0.02 & 0.02 & 1.00 & \\
10. Sales & -0.03 & -0.11 & -0.12 & -0.09 & -0.05 & 0.17 & -0.20 & 0.08 & 0.13 & 1.00 & \\
11. Institutional distance & -0.04 & -0.09 & -0.11 & 0.09 & 0.09 & 0.10 & 0.13 & 0.07 & -0.05 & 0.00 & 1.00 \\
Mean & 0.58 & 0.73 & 0.80 & 20.25 & 0.47 & 10.71 & 55.61 & 39.55 & 59.26 & 202.52 & 7.41 \\
Std. Dev. & 0.30 & 0.27 & 0.24 & 27.32 & 0.32 & 13.46 & 16.23 & 29.40 & 46.23 & 222.39 & 5.13 \\
\hline
\end{tabular}

Note: $N=414$

shareholders (i.e. principals). Even if international diversification could have a positive impact on performance (Ramaswamy, 1993), there is a conflict between the way of working in ownership-concentrated firms in the home market and the required way of working for international diversification that generates a negative relationship between ownership concentration and export intensity.

When firms with a high ownership concentration export to a diversity of destinations, this has a negative interaction in the relationship between ownership concentration and export intensity because it involves more complex information processing. Each country requires different resources to deal with government regulation, trade laws, logistics, cultural diversity, and other factors (Hitt et al., 1997), so the asymmetry of information and control between principals and agents generates a conflict that results in a lower export intensity, which reinforces the results for H1. The majority of exports from the Peruvian firms are commodities and primary products (see Table 1), which see greater price volatility in international markets. Peruvian firms also face greater institutional immaturity and stronger incentives to avoid international market risks.

Our new research findings are consistent with those in the rather limited number of studies that exist on similar topics based on German and Chinese datasets. For instance, in a study based on German manufacturing firms, a negative correlation was identified between the stake of the largest shareholder and export intensity (Oesterle et al., 2013). In a study based on Chinese firms (Liu et al., 2011), entrepreneurial and market orientations were employed as two mediating mechanisms between ownership concentration and export intensity. As a consequence of instability in the local environment and institutions, the principals who have highly concentrated ownership are reluctant to explore new market opportunities in an entrepreneurial fashion. Therefore, they tend to prevent the agents from internationalization activities that usually involve high risks. In a different study based on a Chinese sample, it is found that when ownership concentration is higher than a critical point, the ownership concentration will have a negative effect on export 


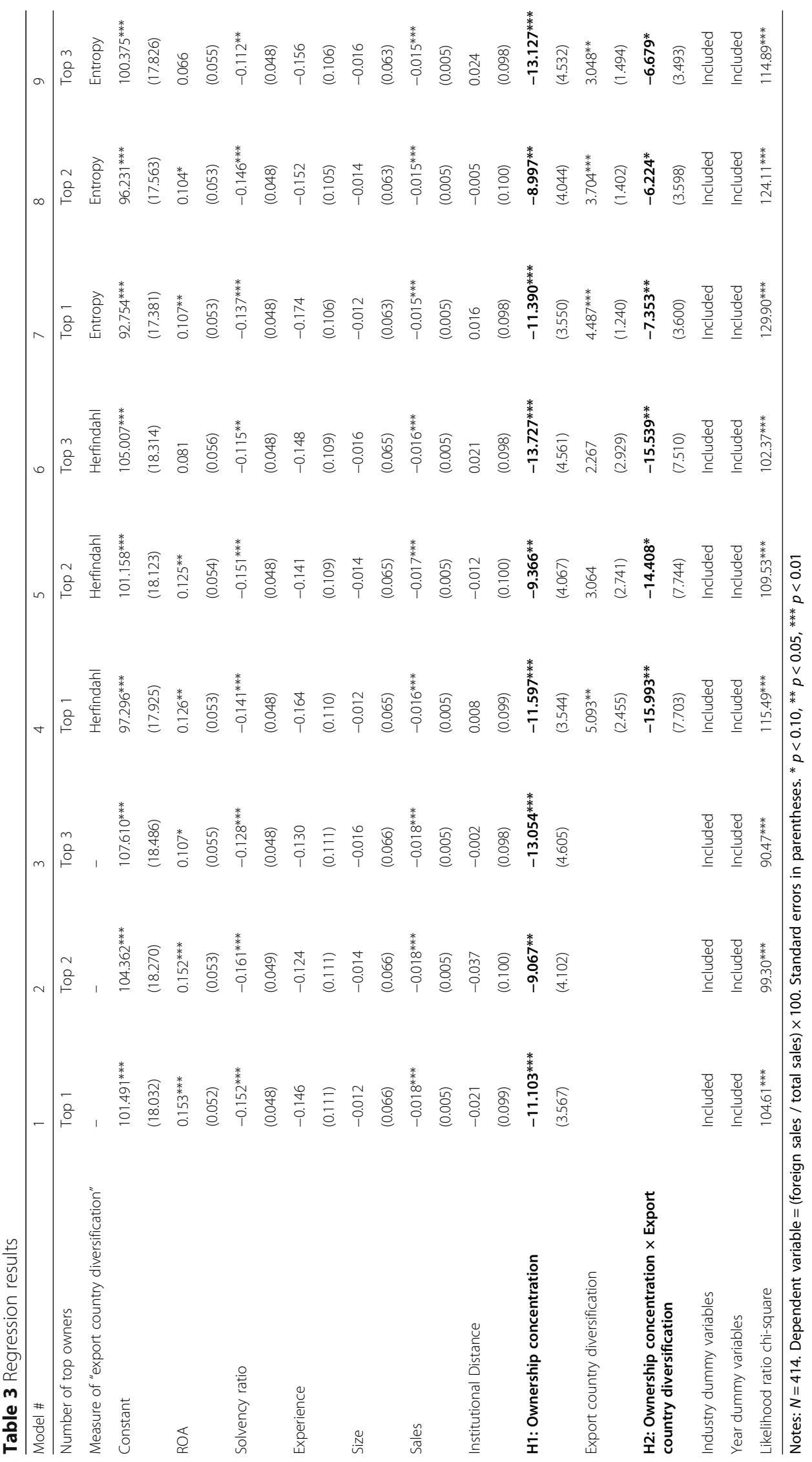


propensity ( $\mathrm{Lu}$ et al., 2009). That is consistent with our findings too, since, as discussed, the ownership concentration in Peru is rather high. Such a similarity between the findings in Peru, Germany and China underscores the importance of institutions in affecting the relationship between corporate governance and exporting behavior (Lu et al., 2009), which also suggests the generalizability of our findings to other economies, e.g. China.

Even if research in China and Peru found almost the same relationship, the reasons are not the same. Previous research based on Chinese firms (Lu et al., 2009) concluded that in a better institutional environment firms tend to have a higher propensity to export; but at the same time, higher ownership concentration makes principals and firms pursue goals different than only profit seeking. Therefore, even if exports are profitable the ownership concentration in China may make firms avoid internationalization and pursue other goals. We argue a negative relationship between ownership concentration and exports, highlighting the risk-averse attitude based on principal-agent conflict. Even in emerging markets that share similar characteristics, this study suggests that more research in different emerging market contexts is needed, since there are still environmental differences within emerging markets that lead to different results.

\section{Theoretical contributions}

First, this study extends the literature on the relationship between ownership concentration and international business commitment from both principal-agent and institutional perspectives, in response to the call to study firm structures, corporate governance, and their consequences (Aguilera \& Crespi-Cladera, 2016). Researchers and practitioners need to bear in mind that corporate governance is different in developed countries and emerging countries because of institutions. In this research, therefore, we scrutinize the institutional background for the relationship between ownership concentration and international business. The findings have strong generalizability as many emerging markets have been found to have similarly high ownership concentration, and their exports rely on highly volatile and uncertain commodities or primary products.

Second, we contribute to a deeper analysis in the internationalization process literature by using not only export intensity but also export diversity as suggested in previous research (George et al., 2005). We incorporate export country diversification into the relationship between ownership concentration and export intensity, and this reaffirms our finding that more complex international processes generate more information asymmetry, cost, etc. and thus greater principal-agent conflict so firms have lower export intensities as a result.

\section{Managerial implications}

The private sector and the government in emerging markets try to increase exports through overseas promotions or similar strategies, because exporting can help local firms to improve their products, processes, and survival rates (Hitt, Hoskisson, \& Ireland, 1994), as they are exposed to the worldwide knowledge pool (Adler et al., 1986). However, the private sector and governments usually do not realize that the principal concern about increasing firms' exports lies inside the firms and home country. By looking into internal factors, one can understand the conflict inside the firm between principals and agents (Bhaumik et al., 
2017), and weak institutions (Cardoza et al., 2016) have an important influence on firms' exports. Thus, providing mature institutions inside the country could enhance firms' exports.

Practitioners can analyze the internationalization process too, bearing in mind the ownership concentration of the firm as a consequence of weak institutions. Therefore, principals should reinforce their efforts to avoid agents' opportunistic behavior in emerging markets, but at the same time the risk and resources for internationalization should be considered to start and continue with sales abroad. In the case of Peru, there is a liberal economy, with a high level of private business and lower participation from the government in the economy. Therefore, we consider the principal-agent conflict in order to explain the export results. However, with other countries such as China, with a socialist economy and more government participation in the economy, one should consider not only the principal-agent relationship but also the principal-principal relationship. Thus, in order to understand and improve exports, practitioners should pay attention not only to the division between developing and emerging markets but also within the intrinsic characteristics of each countries' institutions.

\section{Limitations}

Despite the above theoretical contributions, the interpretation of our findings is still subject to several limitations. First, this research does not distinguish between foreign and local ownership, but all owners do not encounter the same risk, motivations, or interests in controlling or monitoring the strategic decisions of managers in a firm (Ramaswamy, Li, \& Veliyath, 2002; Tihanyi, Johnson, Hoskisson, \& Hitt, 2003). Moreover, different owners bring different specific advantages to the firm (Dunning \& Lundan, 2008). Such analysis could generate interesting results in future studies. Second, innovation is an important element in the export process, and it could be important to include this in future research. For instance, when there is dispersed ownership in the firm, there is more incentive to invest in innovation since the risk is shared with a large number of owners (Aghion, Van Reenen, \& Zingales, 2013). Future research could combine international diversification with country institutions, ownership concentration, and innovation to generate important contributions to the field.

\section{Endnotes}

${ }^{1}$ Minister of International Trade and Tourism of Peru, 2016, Free Trade Agreements of Peru.

${ }^{2}$ If a firm exports in one period to ten different countries, and makes $90 \%$ of its exports to the first country, the exports to the remaining nine destinations are $10 \%$ of the total exports. It does not have a higher diversification than a firm that exports $20 \%$ of its total exports to each of five different countries.

${ }^{3}$ For example, we consider two cases in which $90 \%$ of the goods exported by a firm go to its six largest export destinations. In both cases we assume that the remaining $10 \%$ of the goods exported are divided among ten equal-sized destinations or countries. In case 1 , all six of the largest export country destinations take $15 \%$ of the goods. In case 2, the largest export destination takes $80 \%$ of the total exports and the next five following largest destinations take $2 \%$ each. The six-export country concentration ratio 
would equal $90 \%$ for both case 1 and case 2, but the second case would suggest significant concentration. The Herfindahl index for these two situations makes the lack of concentration in the second case strikingly clear, and the index of country diversification is higher in the first case. In case 1, the Herfindahl index $=0.152 * 6+$ $0.012 * 10=0.136$ and the export product diversity $=1-0.136=0.864$. In case 2 , the Herfindahl index $=0.802+5 * 0.022+10 * 0.012=0.643$, and the export product diversity $=1-0.643=0.357$.

${ }^{4}$ Size value was provided by BvD-Osiris.

\section{Acknowledgements}

We appreciate the comments from the AIB China 2015 (Tianjin, China) and AIB 2017 (Dubai, UAE) on earlier versions of this paper.

\section{Funding}

This research was sponsored by the China Scholarship Council (No. 2012604005).

\section{Availability of data and materials}

1 BvD Osiris database (https://osiris.bvdinfo.com/). Information about return on assets, solvency ratio, sales and size. 2 Peruvian stock market statistics (http://www.bvl.com.pe/). Information to build the ownership concentration variable. 3 Peruvian government customs office (http://www.sunat.gob.pe/). Data on exporting from Peru and industries. 4 The Lauder Institute (https://lauder.wharton.upenn.edu/resources-publications/). Information to build the geographic distance variable.

\section{Authors' contribution}

WV was in charge of writing the drafts. He obtained, cleaned and translated the data, and finally performed the statistical analysis. DZ participated in the organization, correction and supervision of the manuscript and also provided the guidance to use the most appropriate statistical methodology. Both authors designed, read, corrected and approved an extensive number of drafts in order to have this final manuscript.

\section{Competing interests}

The authors declare that they have no competing interests.

\section{Publisher's Note}

Springer Nature remains neutral with regard to jurisdictional claims in published maps and institutional affiliations.

\section{Author details}

${ }^{1}$ Renmin Business School, Renmin University of China, Haidian, Beijing, China. ${ }^{2}$ Vega Salas Corp, Arequipa, Peru.

Received: 21 May 2017 Accepted: 7 November 2017

Published online: 16 November 2017

\section{References}

Adler, N. J., Doktor, R., \& Redding, S. G. (1986). From the atlantic to the pacific century - cross cultural management reviewed. Journal of Management, 12(2), 295-318.

Aghion, P. Van Reenen, J.. \& Zingales, L. (2013). Innovation and institutional ownership. American Economic Review, 103(1), 277-304.

Aguilera, R. V., \& Crespi-Cladera, R. (2016). Global corporate governance: On the relevance of firms' ownership structure. Journal of World Business, 51(1), 50-57.

Bhaumik, S. K., Estrin, S., \& Mickiewicz, T. (2017). Ownership identity, strategy and performance: Business group affiliates versus independent firms in India. Asia Pacific Journal of Management, forthcoming, 1-31.

Bozec, R. (2005). Boards of directors, market discipline and firm performance. Journal of Business Finance \& Accounting, 32(9/10), 1921-1960

Burkart, M., \& Panunzi, F. (2006). Agency conflicts, ownership concentration, and legal shareholder protection. Journal of Financial Intermediation, 15(1), 1-31.

Campa, J., \& Guillen, M. (1999). The internalization of exports: Firm- and location-specific factors in a middle-income country. Management Science, 45(11), 1463-1478.

Cardoza, G., Fornes, G., Farber, V., Gonzalez Duarte, R., \& Ruiz Gutierrez, J. (2016). Barriers and public policies affecting the international expansion of latin american SMEs: Evidence from Brazil, Colombia, and Peru. Journal of Business Research, 69(6), 2030-2039.

Chang, S. J., \& Xu, D. (2008). Spillovers and competition among foreign and local firms in China. Strategic Management Journal, 29(5), 495-518.

Chang, S. J., Chung, J., \& Moon, J. J. (2013). When do wholly owned subsidiaries perform better than joint ventures? Strategic Management Journal, 34(3), 317-337.

Child, J., \& Rodrigues, S. B. (2005). The internationalization of Chinese firms: A case for theoretical extension? Management and Organization Review, 1(3), 381-410.

Collins, J. M. (1990). A market performance comparison of US firms active in domestic, developed and developing countries. Journal of International Business Studies, 21(2), 271-287. 
Contractor, F. J. (2007). Is international business good for companies? The evolutionary or multi-stage theory of internationalization vs. the transaction cost perspective. Management International Review, 47(3), 453-475.

Dawar, N., \& Frost, T. (1999). Competing with giants: Survival strategies for local companies in emerging markets. Harvard Business Review, 77(2), 119-129.

Demsetz, H., \& Lehn, K. (1985). The structure of corporate ownership causes and consequences. Journal of Political Economy, 93(6), 1155-1177.

Demsetz, H., \& Villalonga, B. (2001). Ownership structure and corporate performance. Journal of Corporate Finance, 7(3), 209-233.

Deng, Z., Hofman, P. S., \& Newman, A. (2013). Ownership concentration and product innovation in Chinese private SMEs. Asia Pacific Journal of Management, 30(3), 717-734.

Deng, Z., Jean, R. J., \& Sinkovics, R. R. (2017). Rapid expansion of international new ventures across institutional distance. Journal of International Business Studies, forthcoming. https://doi.org/10.1057/s41267-017-0108-6.

Denis, D. K., \& McConnell, J. J. (2003). International corporate governance. Journal of Financial and Quantitative Analysis, 38(1), 1-36.

Department for International Trade of UK. (2014). Doing business in Peru: Peru trade and export guide.

Dharwadkar, R., George, G., \& Brandes, P. (2000). Privatization in emerging economies: An agency theory perspective. Academy of Management Review, 25(3), 650-669.

Doh, J., McGuire, S., \& Ozaki, T. (2015). Global governance and international nonmarket strategies: Introduction to the special issue. Journal of World Business, 50(2), 256-261.

Dunning, J. H., \& Lundan, S. M. (2008). Institutions and the OLI paradigm of the multinational enterprise. Asia Pacific Journal of Management, 25(4), 573-593.

Fernandez, Z., \& Nieto, M. J. (2006). Impact of ownership on the international involvement of SMEs. Journal of International Business Studies, 37(3), 340-351.

Filatotchev, I., \& Wright, M. (2011). Agency perspectives on corporate governance of multinational enterprises. Journal of Management Studies, 48(2), 471-486.

Filatotchev, I., Dyomina, N., Wright, M., \& Buck, T. (2001). Effects of post-privatization governance and strategies on export intensity in the former soviet union. Journal of International Business Studies, 32(4), 853-871.

Filatotchev, I., Stephan, J., \& Jindra, B. (2008). Ownership structure, strategic controls and export intensity of foreign-invested firms in transition economies. Journal of International Business Studies, 39(7), 1133-1148.

Gaur, A., \& Delios, A. (2015). International diversification of emerging market firms: The role of ownership structure and group affiliation. Management International Review, 55(2), 235-253.

George, G., Wiklund, J., \& Zahra, S. A. (2005). Ownership and the internationalization of small firms. Journal of Management, 31(2), 210-233.

Geringer, J. M., Beamish, P. W., \& Dacosta, R. C. (1989). Diversification strategy and internationalization: Implications for MNE performance. Strategic Management Journal, 10(2), 109-119.

Gomez mejia, L. R., \& Balkin, D. B. (1992). Determinants of faculty pay - an agency theory perspective. Academy of Management Journal, 35(5), 921-955.

Grant, R. M., Jammine, A. P., \& Thomas, H. (1988). Diversity, diversification and profitability among british manufacturing companies, 1972-84. Academy of Management Journal, 31(4), 771-801.

Greenaway, D., Guariglia, A., \& Kneller, R. (2007). Financial factors and exporting decisions. Journal of International Economics, 73(2), 377-395.

Grosfeld, l., \& Tressel, T. (2002). Competition and ownership structure: Substitutes complements? Evidence from the Warsaw stock exchange. Economics of. Transition, 10(3), 525-551.

Grossman, S. J., \& Hart, O. D. (1986). The costs and benefits of ownership - a theory of vertical and lateral integration. Journal of Political Economy, 94(4), 691-719.

Hennart, J.-F., Dongjae, K., \& Ming, Z. (1998). The impact of joint venture status on the longevity of Japanese stakes in U.S. manufacturing affiliates. Organization Science, 9(3), 382-395.

Hill, C. W. L., \& Snell, S. A. (1989). Effects of ownership structure and control on corporate productivity. Academy of Management Journal, 32(1), 25-46.

Hitt, M. A., Hoskisson, R. E., \& Ireland, R. D. (1994). A mid-range theory of the interactive effects of international and product diversification on innovation and performance. Journal of Management, 20(2), 297-326.

Hitt, M. A., Hoskisson, R. E., \& Kim, H. (1997). International diversification: Effects on innovation and firm performance in product diversified firms. Academy of Management Journal, 40(4), 767-798.

Hitt, M. A., Tihanyi, L., Miller, T., \& Connelly, B. (2006). International diversification: Antecedents, outcomes, and moderators. Journal of Management, 32(6), 831-867.

Hoskisson, R. E., \& Turk, T. A. (1990). Corportate restructuring - governance and control limits of internal capital market. Academy of Management Review, 15(3), 459-477.

Hoskisson, R. E., Eden, L., Lau, C. M., \& Wright, M. (2000). Strategy in emerging economies. The Academy of Management Journal, 43(3), 249-267.

Huddart, S. (1993). The effect of a large shareholder on corporate value. Management Science, 39(11), 1407-1421.

Jensen, M. C., \& Meckling, W. H. (1976). Theory of the firm: Managerial behavior, agency costs and ownership structure. Journal of Financial Economics, 3(4), 305-360.

La Porta, R., Lopez-de-Silanes, F., \& Shleifer, A. (1999). Corporate ownership around the world. Journal of Finance, 54(2), 471-517.

Lawless, M. (2010). Geography and firm exports: New evidence on the nature of sunk costs. Review of World Economics, 146(4), 691-707.

Leonidou, L. C., Katsikeas, C. S., \& Coudounaris, D. N. (2010). Five decades of business research into exporting: A bibliographic analysis. Journal of International Management, 16(1), 78-91.

Li, Y., Sun, Y., \& Liu, Y. (2006). An empirical study of soes' market orientation in transitional China. Asia Pacific Journal of Management, 23(1), 93-113.

Li, Y., Guo, H., Yi, Y., \& Liu, Y. (2010). Ownership concentration and product innovation in Chinese firms: The mediating role of learning orientation. Management and Organization Review, 6(1), 77-100.

Liu, Y., Li, Y., \& Xue, J. (2011). Ownership, strategic orientation and internationalization in emerging markets. Journal of World Business, 46(3), 381-393. 
$L u, J ., X u, B ., \& L i u, X$. (2009). The effects of corporate governance and institutional environments on export behaviour in emerging economies: Evidence from China. Management International Review, 49(4), 455-478.

Majocchi, A., \& Strange, R. (2012). International diversification the impact of ownership structure, the market for corporate control and board independence. Management International Review, 52(6), 879-900.

Morales, M., Meléndez, M. J., \& Ramírez, V. (2013). Determinants of ownership concentration in the Chilean stock market. CEPAL Review, 175-188.

Oesterle, M.-J., Richta, H. N., \& Fisch, J. H. (2013). The influence of ownership structure on internationalization. International Business Review, 22(1), 187-201.

Peng, M. W. (2003). Institutional transitions and strategic choices. Academy of Management Review, 28(2), 275-296.

Peng, M. W., \& Heath, P. S. (1996). The growth of the firm in planned economies in transition: Institutions, organizations, and strategic choice. Academy of Management Review, 21(2), 492-528.

Peng, M. W., \& llinitch, A. Y. (1998). Export intermediary firms: A note on export development research. Journal of International Business Studies, 29(3), 609-620.

Perotti, E. C., \& Von Thadden, E. L. (2006). The political economy of corporate control and labor rents. Journal of Political Economy, 114(1), 145-174.

La Porta, R., Lopez-De-Silanes, F., Shleifer, A., \& Vishny, R. W. (1997). Legal determinants of external finance. Journal of Finance, 52(3), 1131-1150

Qian, G., Khoury, T. A., Peng, M. W., \& Qian, Z. (2010). The performance implications of intra- and inter-regional geographic diversification. Strategic Management Journal, 31(9), 1018-1030.

Ramaswamy, K. (1993). Multinationality and performance: An empirical examination of the moderating effect of configuration. Academy of Management Proceedings, 1993(1), 142-146.

Ramaswamy, K., Li, M., \& Veliyath, R. (2002). Variations in ownership behavior and propensity to diversify: A study of the Indian corporate context. Strategic Management Journal, 23(4), 345-358.

Salomon, R., \& Jin, B. (2010). Do leading or lagging firms learn more from exporting? Strategic Management Journal, $37(10), 1088-1113$

Sanders, W. M. G., \& Carpenter, M. A. (1998). Internationalization and firm governance: The roles of CEO compensation, top team composition, and board structure. Academy of Management Journal, 41(2), 158-178.

Santangelo, G. D., \& Meyer, K. E. (2011). Extending the internationalization process model: Increases and decreases of MNE commitment in emerging economies. Journal of International Business Studies, 42(7), 894-909.

Singh, D. A., \& Gaur, A. S. (2013). Governance structure, innovation and internationalization: Evidence from India. Journal of International Management, 19(3), 300-309.

Stopford, J., \& Wells, L. T. (1972). Managing the multinational enterprise: Organization of the firm and ownership of the subsidiary (French ed. Ed.). New York: Basic Books.

Tallman, S., \& Li, J. T. (1996). Effects of international diversity and product diversity on the performance of multinational firms. Academy of Management Journal, 39(1), 179-196.

The World Bank. (2006). Doing business-measuring business regulations http://www.doingbusiness.org/rankings. Accessed.

Thomsen, S., \& Pedersen, T. (2000). Ownership structure and economic performance in the largest European companies. Strategic Management Journal, 21(6), 689.

Tihanyi, L., Johnson, R. A., Hoskisson, R. E., \& Hitt, M. A. (2003). Institutional ownership differences and international diversification: The effects of boards of directors and technological opportunity. Academy of Management Journal, 46(2), 195-211.

Wan, W. P. (2005). Country resource environments, firm capabilities, and corporate diversification strategies. Journal of Management Studies, 42(1), 161-182.

Welch, L. S., \& Luostarinen, R. (1988). Internationalization - evolution of a concept. Journal of General Management, 14(2), 34-56.

Wooldridge, J. M. (2002). Introductory econometrics: A modern approach (2nd ed.). New York: Thomson Learning.

Wright, M., Hoskisson, R. E., \& Peng, M. W. (2005). Strategy research in emerging economies: Challenging the conventional wisdom - introduction. Journal of Management Studies, 42(1), 1-33.

Young, M. N., Peng, M. W., Ahlstrom, D., Bruton, G. D., \& Jiang, Y. (2008). Corporate governance in emerging economies: A review of the principal-principal perspective. Journal of Management Studies, 45(1), 196-220.

Zhou, N., \& Guillén, M. F. (2015). From home country to home base: A dynamic approach to the liability of foreignness. Strategic Management Journal, 36(6), 907-917.

\section{Submit your manuscript to a SpringerOpen ${ }^{\circ}$} journal and benefit from:

- Convenient online submission

- Rigorous peer review

Open access: articles freely available online

- High visibility within the field

- Retaining the copyright to your article

Submit your next manuscript at $\gg$ springeropen.com 